\title{
El ars poética de Miguel Fernández (Evocación en modulema)
}

FRANCISCO RINCON RIOS

Hace ya casi veinte años tuve la oportunidad de vivir una experiencia que para mí, entonces, resultó increíble y sorprendente.

Embarcado en el estudio de los, hasta aquel momento, seis libros publicados de Miguel Fernández, y tras las lecturas de rigor, me obsesionaba la incomprensión de multitud de versos y problemas que se me escurrían inasibles por entre los ojos.

Quería comprender. Saber qué decían y por qué. Pedía explicaciones. Coherencia. Teoría, himnos, adhesiones a grupos y credos. Y Miguel, en su amistosa paciencia, no ofrecía más credos que el de la libertad. Ni más teoría que la materia sagrada. Ni más juicio que el final, ni más canción que la monodia. Ni más política que la del atentado celeste. Ni más sabiduría que la del eros y anteros, sus seis libros.

$\mathrm{Y}$ poco a poco, en tarde interminablemente breves, me encontré junto a Miguel, intentando comprender con él su propia poesía. Comprender yo y comprender él. Era algo que al principio me resistía a admitir. Supongo que fue un acto de perfeta pedagogía, el llevar mis impaciencias de crítico sin estrenar desde el interrogatorio a quien tenía, por principio, las res- 
puestas, hasta esa búsqueda conjunta de significados, en versos en los que él se sentía intensamente implicado, pero no necesariamente hasta su comprensión. Era algo que me resistía a creer. Pero era así. De la oración sustantiva de su verso, él sólo tenía una amplia coda de complementos circunstanciales, y una versión dudosa del sujeto de la acción de tanta circunstancia.

Y así fue como sufrí disfruté esa experiencia - repito lo de sorprendente e increíble- de encontrarme junto a Miguel en tardes revueltas de interrogaciones en las que ya no era yo quien siempre preguntaba, ni él quien nunca respondía.

Sospecho, por lo demás, que con más o menos intensidad, esa experiencia la ha debido tener más de uno de los que estamos aquí, porque formaba parte de su visión de la poesía, de su poesía. A la interpretación de un verso o un poema solía responder con las distintas interpretaciones de críticos y lectores, entre las que nunca se erigía en juez. A lo sumo, y en contadas ocasiones, aventuraba sus preferencias o su visión del tema, ofrecidas en la duda de otra posibilidad.

Esta actitud del poeta no era caprichosa, ni contemporizadora, sino que respondía a su visión de la poesía y del quehacer poético. Por eso ahora. cuando la luz de su presencia se ha hecho definitiva, y el aliciente ha pasado de descubir la poesía de Miguel, a descubrir a Miguel en su poesía, uno de los puntos de encuentro, posiblemente el más incómodo, pero a la vez el más real, sea la forma de entenderse a sí mismo como poeta, o lo que es lo mismo, la forma de ser-se y de crearse, pues como dice Octavio Paz - con sabios de Unamuno- "el poeta es una creación del poema".

En el momento de los diálogos iniciales, a los que antes me refería, Miguel había dedicado ya, aparte del testimonio vivo de sus seis libros, buena parte de uno de ellos a la reflexión y explicitación del terna: me refiero a Atentado celeste, cuyo contenido querría recordar. Su contenido ya ha sido estudiado y reflejado aquí, sin embargo me van a disculpar que lo recuerde una vez más, para acentuar sobre todo una cosa: que la apariencia religiosa que en este libro toma la poesía de Miguel es fundamentalmente una figura literaria. Es decir, recurre al símil de la inspiración 
profética como la forma, el fenómeno más próximo al de la inspiración poética. Pero sólo en ese sentido como el místico, en dirección contraria habla del amor humano y sensual para explicar su relación con Dios. (Como más adelante pondrá de relieve en otros libros).

La autoconfesión artística que ese libro significa, queda patente desde el mismo título, pues desde muy atrás, para el poeta la poesía se define con esas dos palabras de Huidobro. En relación a este sentido de "Atentado" con que considera la poesía, se halla la conciencia de la inspiración y su concepto del poeta. A este último lo considera un "receptor de premoniciones".

Por eso, en "El juego del tarot", fija los límites de sus capacidades:

"Lo que nunca has podido adivinar es qué mano invisible los símbolos ordena.

$\mathrm{Y}$ te queda tan sólo el amado misterio, gruta de tu cobijo y razón que no entiendes".

El poeta es aquí un ser intermedio entre "el médium" y el profeta bíblico, más próximo al segundo que al primero. "Obediencia a la llamada", sobre todo, está escrito en clave bíblica. Su lectura recuerda de inmediato la vocación de Isaías. Idéntica la llamada de una secreta voz que se reconoce. Idéntica la misión que se le encomienda al profeta y la del poeta:

"Hablar en plazas y gritar los trinos".

en la versión de Miguel Fernández. Y profético es el sabor de ese final contradictorio:

"Quien no oyere esa voz feliz se absuelve mas el que medita se destruye".

La idea no es nueva en él, pues ya mucho tiempo antes decía en una entrevista que lo que de especial tenía el poeta era "habitar su eterno exilio". La vocación profética se completa en el centro del poema con el caris- 
ma bíblico, asimismo, de la inspiración, propuesto en clave teológica. Propone en dos figuras sucesivas y superpuestas la inspiración como dictado

"(...) escribiendo

palabras que son tuyas mas te dictan”.

Y la inspiración como soplo:

"soplo que no es susurro y sí es herida".

En esta perspectiva religiosa se comprende la dimensión eterna del momento poético, pues

"este momento es sólo la eternidad".

Esto se haya íntimamente ligado a su concepción de recuerdo:

"Nunca pasó aquello que retorna

$\mathrm{y}$ te ronda tu aire

y aprehendiendo se queda en los ojos".

O como mucho más densamente nos dice en Atentado celeste

"Acontece el suceso

y contemplado se queda ya para siempre".

Esta realidad eternizada en el recuerdo

“(...) siempre es otra

pues ya por meditada se transforma".

Y de esta realidad diversa, "pero más real que aquella"

"nace el sueño". 
$Y$ este es el reino del poeta, a quien en otra ocasión, definía Miguel como aquel "para quien la realidad es sueño". Y sobre todo este mundo se ejerce en el momento imprevisto, la acción misteriosa de la inspiración:

"Mas aquello te nace nuevamente al conjuro

de un silbido delgado que alguien lanza,

de un temblor en los vidrios

cuando un coche rasga la calle solitaria

y sabes que todo lo que vuelve

es dulce como un pífano

igual que las tiernas naranjas que la mesa ruedan

y que nada puede morir

(...)

Porque tan sólo muere

aquello que ya nunca nos crece en la memoria".

La acción del poeta en este momento la estudia en dos poemas diferente, en dos perspectivas irreconciliables. "Disck Jokey" es una ingenua parábola que le sirve para manifestarnos lo más pasivo del poeta respecto a su obra, que tantos poderes taumatúrgicos puede significar para los otros. Pero no para él, que queda como al margen siendo la causa de todo.

"Retrato", poema que capta el poeta en el momento activo de su esfuerzo prometeico, es la cara inversa de la idea. Ahora es el poeta quien posee

"La otra realidad que por sagrada existe

tan sólo en su labor, y que los otros nunca verán si ciegos viven".

La síntesis imposible de ambos aspectos se realiza en el "Tema de Pigmalión".

Por una parte, como veíamos en "Disck Jokey", 
"Si creador de formas, era prohibido el goce

Y menos el amor".

por otra

"quien de alfar alza templos

en solaz los contempla".

El resultado es el milagro final:

"Por amar lo creado

la estatua tuvo vida".

Es la síntesis del "crear para el otro" o "crear para sí". Sólo quien crea en el amor alienta vida. Creación en el amor. Toda creación auténtica es vivificadora, aun prescindiendo de toda otra preocupación didáctica o comunicativa. Y esta realidad

"Tal arrebato es, que sólo se medita

cuando la tierra inventas por haberla vivido".

En síntesis, el proceso lírico sería: la realidad se "somnifica" y al sueño se le anima dándole vida y aliento creador.

Es innegable la coincidencia o aproximación de ciertos conceptos de Miguel a la perspectiva romántica, sobre todo en lo del aspecto misterioso y carismático de la inspiración. Así como la descripción de la misma en clave religiosa y mítica.

Pero sobre esta base romántica, Miguel alza su propio edificio perfectamente ajustado a las características de su labor creadora y sin cuya perspectiva sería mucho más difícil de comprender. Su poesía no es realista. Es sugeridora de sueños, única realidad perdurable. Ambos elementos, sugeridora-sueños, pueden orientarnos sobre el mundo poético de Miguel, tan móvil, $\tan$ inasible. 
Pero este "sueño" del que aquí se habla, obsérvese que no tiene relación con el freudiano ni, por tanto, con el automatismo surrealista. Es otra entidad de tipo ontológico, más relacionada con la psicología del recuerdo, y que es bueno tener en cuenta para no confundir sus resultados, aunque puedan asemejarse sus evocaciones.

Con posterioridad a Atentado celeste, Miguel ha vuelto de nuevo sobre el tema. A veces en alusiones sueltas, a veces con títulos completos sorprendentes, como el poema que acaba ese canto funerario que es Entretierras y que titula "Reencarnación en la palabra".

En este poema describe el proceso de la escritura. Realiza primero su definición, alejada ya de la "revelación" de Atentado celeste":

"La poesía es lo que se descubre".

Nos dice luego que surge de la meditación, y aparece al principio con una túnica tosca. Esta aparición nos recuerda de inmediato aquella otra de J. R. Jiménez, en que la poesía acude vestida de inocencia. Pero esta dama de Miguel no se desnuda, como la musa juanramoniana, sino que se viste con la palabra cálida que teje el sueño, y cobra aliento a medida que la palabra la inventa.

Ha cambiado de referencia, pero sigue en el contexto del poeta creador-demiurgo, que crea en el sueño. Porque, como nos dirá en "Páramo del éxtasis":

"Aquel que en sueños yace, oye el silencio"

Ya no la voz reveladora.

Pero donde retoma el tema de nuevo con insistencia es en ese testamento de sus palabras últimas que es Secreto secretísimo. En él, la palabra reveladora sigue existiendo. La poesía todavía se extraña en el poeta o al revés: el poeta se extraña en su poesía. Pero la voz ya no habla: 
Francisco Rincón Rlos

"De allá que tu respuesta.

Y ya no sé si hablabas".

En Secreto secretísimo cambia de clave. Y es posible que de algo más. Del poema revelación, pasa a centrarse en el poema-sueño, fruto creador del silencio, donde

"La brujería del dormido ve lo soñado".

Así, pues, a la perspectiva de la poesía como dictado y como recuerdo, une aquí la del sueño y añade la de la mudez, la del secreto de las palabras.

En ambas perspectivas, Miguel se halla en esa línea recta que viene desde Platón al surrealismo, pasando por el neoplatonismo de Ficino, la concepción del genio de Diderot, el poeta creador de Herder, el soñador de Novalis y el poeta del inconsciente de Breton y que tiene de común la visión de la inspiración pética como irrupción de la "otredad" en el propio yo, sea en forma de musa, de Dios cristiano, de irrupción del genio o del rescate arriesgado del sueño y del inconsciente. Siempre es la otredad, la ajena (musas-Dios) o la propia otredad del hombre escindido de la edad moderna, sea con su propia genialidad, o sea con su propio inconsciente, mucho más ajeno a sí mismo que las musas o demonios que en otros tiempos lo habitaron.

Al principio de estas páginas decía que el ars poética era quizás el mejor punto de encuentro, el más seguro, pero también el más incómodo.

La visión de Poe-Baudelaire-Mallarmé, la del poeta artífice (frente al autor poseso); o el apolíneo frente al dionisíaco, de Nietzsche, tan de nuestros días, en la que nos encontramos y nos reconocemos con tantos poetas de hoy, no es la de Miguel.

Esto, en principio, produce cierta desazón y cierto deseo de evitar el tema. A pesar de la subversión que en él produce el surrealismo, la perspectiva se nos ofrece como inevitablemente pasada, fruto de una visión ingenua de la vida, o de un exceso de fe en el hombre. 
Sin embargo es un aspecto fundamental de la poesía y del poeta, sin el que es difícil adentrarse en la obra de Miguel, y de comprenderlo a él como creador.

Por supuesto, al principio de su obra, cuando su credo era la libertad en medio de la opresión reinante, el poeta no era un creyente neoplatónico, ni menos un ingenuo neopagano. Sin embargo su mundo poético tiene voces que hablan.

Pero en un periodo, como el de los años cincuenta, en que hay una fuerte corriente de poesía religiosa, en el que el "tú" interlocutor de tanto verso se llama Dios, para los hijos de la ira y para los dueños del diálogo, Miguel nunca dice de quién es la voz que dicta y comete el atentado celeste de su poesía. Oye la voz, la constata. Existe. Describe su acción, pero no reconoce o no revela el origen.

Atentado celeste es el tercero de los libros de Miguel. Con Credo de libertad y Sagrada materia han dibujado (o mejor, borrado) los límites de su mundo. En ese mundo, escribir no es una actividad cualquiera, aleatoria, un oficio junto a otro. Escribir es una forma de vivir. Es la elección de un sistema de vida. Una forma de vida inexistente. Que no es la de ser poeta. Que hay que crearla. Y en esa creación se compromete, seguramente después de muchas dudas y titubeos. Tras la decisión, un mundo compulsivo se le revela y se le desvela. Es toda la materia sagrada, ungida por el don y el arrojo del poeta. Es

"la otra realidad que por sagrada existe
tan sólo en su labor
y que los otros nunca verán si ciegos viven".

Es como algo que se le ha revelado en su decisión de vida. A partir de ahí, de la metáfora bíblica de la percepción de la realidad, el poeta comienza su obra. Esa impresión de algo que le ha sido dado no lo abandonará nunca, pero tampoco insistirá en ella.

Cuando vuelve sobre el tema, en Atentado celeste, en Secreto secretísimo y en tantos poemas y alusiones, la perspectiva se ha transformado. No 
se conforma con la constatación del hecho, con la existencia de la voz. Lo que busca es la identificación, la descripción de la voz y sus poderes.

El silencio aparece como leitmotiv en Secreto secretísimo. La meditación y el sueño incuban la palabra. Se refiere, por supuesto, a la palabra creadora, a

"la palabra cálida que el sueño teje...".

Pero para llegar al parto ha de hacerse la tiniebla total.

"Sólo ve la luz y la palabra

cuando tiniebla es todo".

No se trata de ese tópico de la luz que brilla más en las tinieblas, o ese otro de que cuando todo aparece apagarse se abre una luz de esperanza. No, se trata de la tiniebla de la nada, del silencio total de las cosas y las realidades, de donde surgirá la palabra que crea, la que

"sólo por pronunciarla

será una génesis nueva".

El silencio. La mudez, como dirá mucho más rudamente. Ese es el hallazgo en Secreto secretísimo. Y cuando el silencio, por fin, se rompe

"tal grito no fuera lo real.

Y por ello tú crees lo que dijo.

Aquello nunca dicho".

"Lo nunca dicho" surge cuando "enmudece la mudez".

Estamos en el retruécano y el balbuceo de la explicación inexplicable.

Pero el poeta insite una y otra vez.

"Es la contemplación de lo no visto

lo que enmudece la mudez". 
Aparece el tema del sueño, pero lo soslaya y lo sacrifica al más inexpresivo de la mudez. El sueño ha sido una corriente poderosa en la poesía actual. Pero su sueño no es el surrealista, el sueño de la liberación de los barrotes de la consciencia, de donde surgiría libre la poesía. Ni el sueño onírico o revelador de Coleridge. Y ni siquiera el sueño-ensueño de Novalis, que se transforma en mundo y reinventa la realidad, posiblemente el más próximo a su concepción. El sueño del que nos habla es el de la nada, el de la negación de toda realidad. Sólo en él aparacerá un mundo nuevo. El sueño de la mudez. Lo más duro para el poeta, el hombre de la palabra. La mudez absoluta, hasta lograr que ésta enmudezca.

Dos años más tarde, quizás por última vez con tanta intensidad, Miguel vuelve sobre el tema en ese libro del humor leve y socarrón que sólo proporciona la sabiduría densamente adquirida con la experiencia, que es la esencia de Bóvedas. En él no busca nuevos paradigmas para definir su forma vida y de expresión. Simplemente acude a los ya dados, y nos lo ofrece de nuevo con una leve sonrisa burlona en el tono.

El soplo, la primera definición de su numen, por si hubiera duda, queda desacralizado por el aroma del vino:

"El diván de peluche, el escabel marrueco, me acomodan.

Ya tan horizontal como los mares,

al techo ojiva miro cincunflejo.

$\mathrm{Y}$ se pasean ángeles beodos.

Y al oído me dictan sus proclamas.

Y así la luz encuentro del poema".

No se trata, por tanto, de una vuelta a lo romántico, a sus actitudes y visiones, con ser tan atractivas.

Miguel busca una poesía en la que la inspiración, la palabra poética, brote de esta forma nueva de ver las cosas. Entre la negación al juego que llamamos realidad y la creación de algo, aún indecible, hay una voz, un ansia, una desazón, una búsqueda, un sueño, una mudez que a veces 
habla, que le habla. Que se-le habla. Esa es la inspiración y ese su ars poética, que se transmuta a su vez, en ars vivendi y en ars moriendi. Pues como predecía en Las flores de Paracelso
"Cuando llegado el trance, quebrada la vasija
el agua clara ya vertida en bruces
por tierra roja abreve,
tú me reencarnarás.
Jardín del ansia".

Algo similar ocurre con el tema del sueño y la mudez, que sintetiza en el poema del "Dormido":

"El eterno dormido llega al sueño,

y allí ángeles de negror y de blancura

le van poblando en sienes otros mundos

que nunca vio.

$\mathrm{Y}$ en esa duermevela

grita con coraje

o canta una salmodia.

Tal vez lo que ya lúcido viviera

sin haberlo vivido:

la invención de estos mundos de la nada".

La idea la reitera de una forma mucho más conceptual en los "Ciclos de la palabra", donde tras las sucesivas mutaciones de la creación, ser poeta se transforma en

"vivir soñando los inventos

de esa función vocal"

que por supuesto es la palabra. 
Es la misma conclusión que de forma más gráfica, nos dirá en "Juegos de magia”.

"Prendí antorcha al pajar

y ardió el misterio.

$Y$ quedé tan huérfano

que magia sólo es ya mi palabra".

Decía al comenzar, que sin querer, en la lectura del poeta había pasado, de buscar la poesía de Miguel, a rastrear a Miguel en su poesía. De esa forma, el intento surcado de limitaciones de este artículo era apoyar a otros seguro más sabios, no más sentidos, para así entre todos, hacer realidad la fórmula nigromántica de la resurrección que él nos daba en "Palingenesia”, el último poema del libro mágico de Las flores de Paracelso:

"Llevadle su mortaja a ese universo

húmedo donde el sol acuna al polen,

al venero del llanto de la tierra

y dejarla que duerma".

(...)

Regad luego a las vísperas con lágrimas

su campo débil.

Aventad briznas rojas;

que infantillos de coro canten su letanías

y alzad el corporal.

La rosa resurrecta os glorifica

Nacida queda de la muerte pura". 